\title{
The Rise and Decline of the Male Breadwinner Family? An Overview of the Debate
}

\author{
Angélique JansSENS
}

\section{INTRODUCTION}

In recent years feminist scholars have called for a complete rethinking and revision of the foundations of labour history as a necessary prerequisite for the integration of gender as a core concept into histories of labour and social class. In this attempt one of the most deeply rooted assumptions in male-oriented labour history needs to be identified and made subject to careful rethinking, namely the assumption that the public and the private sphere should be seen in terms of an essentially gendered opposition.' Undoubtedly, one of the most powerful images used not only to represent but also to justify the gendering of the public and the private sphere is the image of the male breadwinner family and the male household head as the sole provider for his dependent wife and children. For this reason, the articles in this volume are all firmly at the heart of what may currently be seen as the crucial intersections in the history of labour, gender and social class.

At the same time, the male breadwinner family is the focus of many pressing academic and policy concerns, receiving ample attention from historians and social scientists alike. In a recent review article, Colin Creighton summarized the ongoing historical and sociological debates on the male breadwinner family, calling for integration and synthesis. ${ }^{2}$ It is tempting to relate this renewed interest in the male breadwinner family to its apparent demise in most parts of the Western world. Since roughly the 1960 s or 1970 s most Western countries have experienced a remarkable and substantial rise in female labour force participation. This is undeniably one of the major historical developments of the modern era. Partly in response to the current crisis of the welfare state, national governments have begun to implement social policies which are increasingly based on the principle of economically independent individuals rather than on the male breadwinner family.

In the history of male breadwinning, two important sets of questions stand out for investigation, and all the articles in this volume reflect on each of them. First of all, there is the issue of the precise development

See Sonya Rose, "Gender and Labor History. The Nineteenth-Century Legacy", in Marcel van der Linden (ed.), The End of Labour History?, International Review of Social History, Supplement 1 (1993), pp. 145-162.

2 Colin Creighton, "The Rise of the Male Breadwinner Family: A Reappraisal", Comparative Studies in Society and History, 38, 2 (1996), pp. 310-337.

International Review of Social History 42 (1997), Supplement, pp. 1-23 
over time. In his recent review of the debate, Colin Creighton asserted that the outlines of the development of the male breadwinner family are now well established, implying that debates over this issue may be closed. ${ }^{3}$ The contributions in this volume suggest that this may be an over-hasty conclusion, perhaps inspired by a heavy reliance upon British evidence to the neglect of other countries in Europe and certainly those in the nonWestern world. This volume makes it clear that breadwinning practices varied greatly over time and space, from one neighbouring community to the next, between different parts of the world, and between different families in one and the same locality. I would like to link up with Horrell's and Humphries's conclusion in this volume where they stress that "systematic empirical investigation of the male breadwinner family has been lacking" and that "even the timescale of its appearance and development remains obscure".

The second important set of questions that needs to be addressed with regard to the male breadwinner family concern the factors responsible for its origin and expansion. Even a small excursion into this field will reveal that it abounds with controversy. Arguments range from economic explanations stressing the importance of rising male earnings to the contention that the male breadwinner family arose out of an unfortunate marriage between patriarchy and the industrial capitalist system. Recently, more complex explanations of the origins and the expansion of male breadwinning have been advanced, resulting in the identification of a wide range of factors relevant to the problem. Employers' strategies, seemingly gender-neutral labour market factors and processes of capital accumulation, concepts of masculinity and the complicated interactions between family strategies and the labour market, or indeed the role of institutional structures of power are some of the factors that have come to enrich the debate on male breadwinning. However, they have also left the debate to some extent in a state of confusion and fragmentation. The time has come for us to begin to tie up the various loose ends and to move beyond fragmented accounts towards the formulation of "theories of the middle range" which are both complex and sensitive to historical variation and context. One of the ways in which we can make progress in this direction is to develop detailed systematic comparisons. I hope that the articles in this volume will constitute important steps towards this goal. In this connection, I would like to stress that it is paramount to move away from an exclusively European focus and to include comparisons with non-Western histories of breadwinning. By including examples from the Western as well as the non-Western world, while ranging from the late eighteenth century to recent decades of the twentieth century, the articles in this volume offer new and encompassing histories of male breadwinning.

${ }^{3}$ Ibid. 
Before entering into a discussion of each of the two sets of questions in relation to the articles in this volume, it will be useful to engage in a brief discussion of the definition of the concept of the male breadwinner family. The term "male breadwinner family" refers to a particular model of household organization in which the husband is the sole agent operating within the market sector, deploying his labour in order to secure the funds necessary to support a dependent wife and children. In exchange, the wife assumes responsibility for the unpaid labour required for the everyday reproduction of her husband's market work, such as cooking, cleaning and laundering. In addition, she provides for the intergenerational reproduction of labour: the bearing and raising of children. Through this parental division of labour, the children are exempted from productive activities until a given age and are provided with time for education and personal development. Or to put it differently, in the terminology employed by Lena Sommestad in this volume, male breadwinning may be seen as a particular way of organizing human reproduction. Although the ideology of male breadwinning precludes waged labour by either the wife or the couple's children, the employment of the latter, whether male or female, seems generally to have been viewed differently from the employment of the spouse. Male pride in being the family breadwinner seems to have been much more seriously undermined by the paid employment of wives than by that of children. ${ }^{4}$ Finally, a concept of the male breadwinner family which focused exclusively on the issue of paid employment to the neglect of economic activities with less visible monetary links, such as selfprovisioning, would unnecessarily limit the value of this concept as an analytical tool, in both historical and cross-cultural terms.

\section{THE RISE AND FALL OF MALE BREADWINNING?}

Returning to our two sets of questions, let us look first at the historical development of male breadwinning. Within the debate on the social and economic status of women in pre-industrial societies, some scholars argue that prior to the nineteenth century men and women engaged in egalitarian marriages in which both partners shared in productive work and what would now be seen as "domestic" work, and that (despite a clearly gendered division of labour) the contribution of women was looked upon as socially and economically valuable. A classic in this field is the study by Alice Clark on women's work in medieval and early modern England.

Wally Seccombe, "Patriarchy Stabilized: The Construction of the Male Breadwinner Wage Norm in Nineteenth-Century Britain", Social History, 11 (1986), pp. 53-76.

3 Alice Clark, Working Life of Women in the Seventeenth Century (London, 1982; 1st ed. 1919). Others are: A. Oakley, Housewife (Harmondsworth, 1976); S. Lewenhak, Women and Work (Glasgow, 1980). For surveys of the debate see for instance: Olwen Hufton. "Women in History: Early Modem Europe", Past and Present, 101 (1983), pp. 124-141, 
Clark argues that women lost their important economic role in the course of the seventeenth century, whilst their status as independent individuals became eroded as a result of the emergence of capitalist methods of production characterized by individual wage labour and the separation of home and workplace. Research into women's role in economic development in non-Western societies likewise indicates the important role of women in traditional agriculture. These authors argue that, although there has been a division of labour between men and women in most traditional rural societies, this division was (with-the clear exception of the Arab world) horizontal and non-hierarchical. ${ }^{6}$ In rural societies in Europe, female labour was similarly of vital importance to the family economy. Lena Sommestad points out in her contribution to this volume that Sweden, as a basically rural society, was heavily dependent on the labour of both unmarried and married women until well into the twentieth century. In agricultural production the role of married women was crucial, although limited to either economically inferior activities or activities which tied women exclusively to their homes. As a rule, agrarian women were engaged in heavy physical work in the fields, including piling hay, picking tomatoes, or even ploughing.

In the urban context, there is also evidence of women engaging in productive activities outside the home. In eighteenth-century England, women and girls may be found working as apprentices and craftswomen in a wide range of crafts, although it is unclear whether men and women were equally represented in crafts traditionally associated with men.? In a recent study of eighteenth-century Edinburgh, Elizabeth Sanderson demonstrates the extensive representation of women in the operation of various types of retail businesses, primarily in the clothing sector. Sanderson insists that these were skilled trades and that women were in no sense marginal to the Edinburgh business community. ${ }^{8}$ Similarly, Jenneke Quast concludes that sixteenth-century Dutch urban women were economically active in the textile industry and the retail trade, both as independent masters and craftswomen and as wage workers. However, she also identifies various attempts to exclude women from independent occupations and to deny them access to guild organizations, which she assumes to be part of a very gradual process of the economic marginalization of women. ${ }^{9}$ By contrast, in a study of the seventeenth-century Leiden textile industry, Els Kloek

or Harriet Bradley, Men's Work, Women's Work. A Sociological History of the Sexual Division of Labour in Employment (Oxford, 1989), pp. 33-42.

'Esther Boserup, Women's Role in Economic Development (New York, 1970).

7 See Bradley, Men's Work, Women's Work, p. 37; K.D.M. Snell, Annals of the Labouring Poor (Cambridge, 1985), pp. 270-319.

B Elizabeth Sanderson, Women and Work in Eighteenth-Century Edinburgh (London and New York, 1996).

"Jenneke Quast, "Vrouwenarbeid omstreeks 1500 in enkele Nederlandse steden", in Jaarboek voor Vrouwengeschiedenis, vol. 1 (Nijmegen, 1980), pp. 46-64. 
disputes the idea of gradual exclusion of women from independent craft production in the early modern period on the grounds that female labour appears always to have been marginal to the organization of the Leiden textile trade. Female textile workers did not have their own trades, but worked as assistants to their husbands or as day labourers with independent craftsmen (although as widows they might keep on their deceased husband's business). ${ }^{10}$ Hettie Pott-Buter's conclusion in her study of female labour and family patterns is in line with this, in so far as that she states that male breadwinning was already firmly established as the dominant family ideal in seventeenth-century Dutch society, while high standards of living brought this family ideal within reach of large proportions of the population. ${ }^{11}$

It is important to note that not all critics in the opposing camp - for instance, historians such as Edward Shorter, Martine Segalen or Gay Gullickson - deny the important economic role played by women. Their criticism focuses more on women's assumed independent social and economic status, pointing out that women were confined to the home, that their economic activities were seen as inferior to those of males and that women's work was nearly everywhere strictly segregated from men's. ${ }^{12}$ Although in the urban context women appear in all trades and occupations, the work they did was closely linked to their marital status and position in the life course. Women usually had access to work through their fathers or husbands, acting as their assistants or at best as co-workers.

In her assessment of women's economic position in pre-industrial societies, Harriet Bradley's primary conclusion is that work was sexually segregated, with women being restricted to carrying out tasks more firmly centred on the home, or at least to a much nartower range of occupations than men. ${ }^{13}$ However, she also stresses both the variety of male and female work pattems and the flexibility that seems to be inherent in most preindustrial gender divisions of labour. She rightly relates this flexibility in the labour system to the economic uncertainties of pre-industrial societies, in which families were forced to adopt flexible work patterns in order to survive. In addition, the system of family-based production forced households to juggle the labour capacity of all their members to fit changing economic conditions.

The argument that the economic precariousness of working-class life forced families to deploy the labour resources of all their members, includ-

${ }^{10}$ Els Kloek, Wie hij zij, man of wijf. Vrounengeschiedenis en de vroegmoderne tijd (Hilversum, 1990), pp. 48-77.

${ }^{11}$ Hettie Pott-Buter, Facts and Fairy Tales about Female Labor, Family and Fertility (Amsterdam, 1993). See in particular pp. 319-321.

${ }_{12}$ E. Shorter, "Women's Work: What Difference did Capitalism Make?". Theory and Society, 3, 4 (1976), pp. 513-529; M. Segalen, Love and Power in the Peasant Family (Oxford, 1983); Gay L. Gullickson, Spinners and Weavers of Auffay. Rural Industry and the Sexual Division of Labor in a French Village, 1750-1850 (Cambridge, 1986).

${ }^{13}$ See Bradley, Men's Work, Women's Work, pp. 38-39. 
ing the labour of wives and children, is extended into the industrial era by Mike Hanagan in his contribution to this volume on family wage demands in France in the nineteenth century. Whilst stressing the wide variation in women's employment patterns in the industrial area of the Stéphanois, Hanagan argues that the families of miners, weavers and metalworkers could not afford to "narrow the scope of wage earning" by withdrawing their wives and children from the workforce. The only group of Stéphanois workers with wives not involved in waged work were the glassworkers of Rive-de-Gier, a well-paid elite whose high standard of living seems to have attracted ample interest in the contemporary imagination. It appears, therefore, that family employment patterns amongst the working classes in the Stéphanois were shaped much more by demand-side factors - in other words, by the availability of suitable employment for women and girls - than by socio-cultural constraints such as workers' aspirations for male breadwinner respectability or masculinity.

Much of the writing on male breadwinning has been heavily influenced by British authors, who contend that, even amongst the working classes, families had already become solely dependent on the earnings of the male head of household by the end of the nineteenth century. The assumption is that women's participation rates declined steadily from the early decades of that century, while compulsory schooling removed employment opportunities for children in the closing decades. In their paper in this volume, Sara Horrell and Jane Humphries even conclude that for "many families in a variety of economic circumstances the dependence on a male earner preceded industrialization"; in other words, they situate the development in the later decades of the eighteenth century. However, their data also indicate that sole male breadwinning existed primarily in the initial stages of the family life cycle. In the later stages, when family heads were aged forty or over, children began to be responsible for large proportions of the total family budget. ${ }^{14}$ Horrell and Humphries also draw our attention to the fact that, given high levels of mortality and economic insecurity, most working people's lives included some time spent outside the male breadwinner family.

There are sufficient indications to argue that it is not possible to generalize from the British experience when discussing other countries in Europe, or elsewhere. For instance, around 1900 the majority of working-class families in Ghent were still heavily dependent on the contributions of

14 In another paper by Sara Horrell, written together with Deborah Oxley, on the household budgets of British industrial workers around 1890, it becomes clear that even amongst the better-paid workers the family could not survive without their children's labour: see "Breadwinning, Poverty and Resource Allocation in Late Nineteenth-Century Britain", unpublished paper for session B17 of the forthcoming Twelfth International Economic History Congress, to be held in Seville in 1998. 
wives and children to the family budget. ${ }^{15}$ Wives contributed primarily in the earlier stages of the family life cycle, when the household head was still under thirty years of age; depending on the husband's occupation, wives were gainfully employed in between around 50 per cent and 85 per cent of the families. From that point onwards, children began to take over from their mothers as supplementary wage earners, so that by the time household heads reached the age of fifty about half of the family budget came from earnings by family members other than the household head. It is also true, however, that as soon as wage levels seemed sufficient, some of these Ghent families, notably those of artisans and metalworkers, were prepared to forgo the earnings of wives and mothers to procure the prestige and status of a "male breadwinner family".

Similarly, there is a growing body of evidence relating to late nineteenth- and early twentieth-century Spain revealing the inadequacy of the male breadwinner model for large groups of the working population. By taking in lodgers and providing them with meals and laundry services, miners' wives in the early twentieth-century Basque country were able to assume responsibility for large proportions of the total family budget, sometimes contributing more than their husbands. ${ }^{16}$ Similarly, in fishing communities in Galicia during the same period it was impossible for families to forgo the paid employment of wives and mothers: here, the majority of married women worked for wages in the fishing and canning industries, even if in the older age category of forty and over. ${ }^{17}$

Another important writer on the issue of family forms and patterns of breadwinning, Wally Seccombe, has made strong statements concerning the history of the family in north-western Europe, claiming that the form of family organization by which men go out to earn the family's primary income while women stay at home to care for the family should be regarded both as a recent innovation and as historically exceptional. ${ }^{18}$ Seccombe locates the gradual emergence of this exceptional family form amongst working-class households in the course of the nineteenth century and believes that it reached its heyday in the 1950s. We are urged to accept that the recent mass entry of women to the labour market represents

is Patricia Van den Eeckhout, "Family Income of Ghent Working-Class Families ca. 1900", Journal of Family History, 18, 2 (1993), pp. 87-110.

${ }^{16}$ Pilar Pérez-Fuentes, Vivir y morir en las minas. Estrategias familiares y relaciones de género en la primera industrialización vizcaína: 1877-1913 (Bilbao, 1993). See in particular pp. 274-275.

17 Luisa Muñoz, "The Family as a Work Group. Technological and Workplace Changes in Occupation in the Galician Fish-Canning Industry, an Empirical Case in Bueu, 18701930", paper presented at the Third Workshop on Family Economies and Strategies, Universitat Pompeu Fabra, Barcelona, March 1997.

18 Wally Seccombe, Weathering the Storm. Working-Class Families from the Industrial Revolution to the Fertility Decline (London and New York, 1993). See in particular pp. 202-209. 
a return to the historical norm, rather than a breakdown in traditional ways of family organization.

Finally, it should be borne in mind that the notion of the male breadwinner family is a concept originating in Westem family ideology. In line with the statements made earlier regarding women's position in most non-Westem societies, the study by Samita Sen in this volume highlights the productive role of women and children in agricultural and artisanal households in nineteenth- and twentieth-century India. Women worked on the family farm, reared cattle or processed grain, and engaged in (domestic) textile production or even in the production and trading of fuel; through these and other economic activities women sometimes contributed up to, or even more than, half the total family income. Nevertheless, women's earnings were still seen as "supplementary" to those from male sources. As Sen argues, even though the notion of a single male provider was not ubiquitous in Indian society before the $1950 \mathrm{~s}$, it was already institutionalized in the family's property and labour arrangements, which subordinated women and children. After the 1950s, however, the notion of male breadwinning and female domesticity also gained ground in India, particularly amongst the country's elite.

However, variation in married women's contributions to family income is not wholly absent from the non-Westem world either. Indeed, it would seem that variation is even greater outside Europe than within it. For instance, in Latin America and the Hispanic Caribbean the cult of female domesticity and the emphasis on men as sole family providers was and is even stronger than in European family history. The roles of women and men were sharply divided through the basic distinction between the casa or home, the domain of women, and the calle or street, which was the domain of men. This division between a private and a public sphere ensured the economic dependency of women on men. However, even in Central and Latin America, the male breadwinner family model was not universal: it was certainly not the dominant family model amongst the black/mulatto or indigenous/mestizo working classes. ${ }^{19}$ For example, in early nineteenth-century Mexico, women constituted one-third of the labour force, although it was largely poor women who worked and the majority of these women were either single or widowed. In all racial groups, single women and widows worked more often than married women. On the other hand, the Afro-Caribbean population never developed an ideology of female economic dependency upon men because black slave women had been dependent on their own labour to provide for themselves and their children. Furthermore, consensual unions, which were much more frequent amongst Afro-Americans than amongst other racial groups in the Caribbean, helped to weaken dependency on a male

19 Helen I. Safa, The Myth of the Male Breadwinner. Women and Industrialization in the Caribbean (Boulder, CO, 1995), pp. 47-52. 
breadwinner because the women concerned bore greater economic responsibility for their children than legally married women. It is not surprising, therefore, that between 1899 and 1920 Cuban labour force participation rates were three to five times higher amongst Afro-Cuban women than amongst white women. Obviously the lower income levels amongst the Afro-Americans are another explanatory factor. Nevertheless, Cuban female activity rates in urban areas were among the lowest in America; ${ }^{20}$ even in 1953, the figure was only 24 per cent. By contrast, most Latin American countries in the 1940 s and 1950s had activity rates for urban women that were amongst the highest in the world, ranging from 32 per cent in Argentina to as much as 73 per cent in Haiti. ${ }^{21}$ Differences in urban female activity rates in the non-Western world in the middle of the twentieth century cannot be related exclusively to national levels of economic development, as might perhaps be assumed. A huge amount of variation existed; contrast, for instance, the Latin American figures quoted above with the participation rates for countries such as India, Pakistan and Egypt, which were as low as 3 to 14 per cent. The latter three countries might be characterized as exhibiting an "early marriage and female exclusion" model heavily influenced by Muslim attitutes towards women. ${ }^{22}$ The early and universal pattern of marriage in most Islamic countries is connected with the prohibition on public activity on the part of women and the insistence that they should focus their attention exclusively on husband and children. Clearly, historical and cultural explanations concerning the relationships between family, gender and the economy must be deployed to account for global differences in breadwinning patterns.

In summarizing this brief overview, we may first of all state that the sole male breadwinner has been a powerful ideal in most Westem societies. However, to what extent the male breadwinner family has been predominant in empirical reality is still open to dispute. Seen within a longterm and global perspective, the male breadwinner family may appear as a historical exception, confined to specific countries or regions in the Western world or to certain limited periods in the historical development of these areas. Nevertheless, there is no doubt that, while breadwinning patterns have varied enormously from one period, region or industry to another, as well as at different points in the family life cycle, sexually segregated systems of labour division have everywhere determined men's and women's work activities in a more or less rigid way. It is clear that the debate on the male breadwinner family has suffered from the often

\footnotetext{
${ }^{20}$ See Safa, The Myth of the Male Breadwinner, p. 50.

21 Andrew Collver and Eleanor Langlois, "The Female Labor Force in Metropolitan Areas: An International Comparison", Economic Development and Cultural Change, 10, 4 (July 1962), pp. 367-385.

22 See ibid., p. 375. A note of caution seems appropriate here. The official statistics obviously do not cover all the economic activities that poor women may undertake in the home, varying from domestic production to self-provisioning activities.
} 
diffuse, indirect and scattered nature of the historical evidence that has been brought to bear. Decisive conclusions concerning breadwinning practices can evidently only be based on direct evidence such as is contained in family budgets, as opposed to indirect or impressionistic evidence stating or denying the important contributions of women and children to the family economy. For this reason, the time has come to launch a systematic cross-country comparison of breadwinning patterns based on family budgets in conjunction with other related evidence. It is time for a systematic "Reconstruction of the Male Breadwinner as the Historical Norm".

\section{BETWEEN SWEEPING THEORETICAL STATEMENTS AND COMPLEX HISTORICAL EXPLANATIONS?}

How can we explain patterns of breadwinning or, to be more precise, identify the factors responsible for the rise and expansion of male breadwinning? In recent years the debate on how to explain women's economically subordinate position has shifted from more schematic accounts with universalistic pretensions to studies that are more sensitive to historical variation and complexity. Within the debate on male breadwinning, a number of different approaches may be distinguished and the articles in this volume all touch upon several of the key issues. ${ }^{23}$ I shall briefly discuss the main outlines of the debate, again without pretending to provide a complete overview, and situate the contributions in this volume within it. As a collection, these papers help to meet the need for more complex, historically sensitive and integrated approaches to the attempt to explain the male breadwinner family.

Economists and economic historians tend to explain female labour force participation and patterns of breadwinning by reference to standard models of labour supply. The supply of female labour, as seen in neoclassical economic theory, is determined by typical supply-side variables such as a woman's age and marital status, the total family income, and her husband's and her own earning power. ${ }^{24}$ In most twentieth-century Western economies, there is evidence of the so-called "income effect" which means that the more husbands earn, the less wives will work, irrespective of their theoretical earning power. However, the substantial rise in female labour force participation in more recent decades, and thereby the demise

${ }^{23}$ Some parts of the following account are based on the excellent review article by Creighton, "The Rise of the Male Breadwinner Family".

24 Additional supply-side variables for female labour force participation are numbers and ages of children present in the household. Whereas in more recent times the presence of very young children has had negative effects on labour force participation by married women, this effect is not generally found in more historic populations. See the article by Humphries and Horrell in this volume, or T.J. Hatton and R.E. Bailey, "Female Labour Force Participation in Interwar Britain", Oxford Economic Papers, 40 (1988), pp. 695718. 
of the male breadwinner family, can only be explained by assuming a more dominant positive effect of the woman's own wage rate in the market, known in economists' jargon as "the substitution effect". Thus, in families where husbands' incomes are similar, the more the wife is capable of earning in the market, the more she will work. ${ }^{25}$ Examples of a neoclassical economic approach may be found in the discussions of workers' living standards in England during the Industrial Revolution by Peter Lindert and Jeffrey Williamson, or in Hatton's and Bailey's analysis of fermale labour force participation in England in the 1930s. Supply-side factors also figure prominently in recent explanations of the consistently low labour market participation by married women in the Netherlands. In her comparison of nineteenth-century Dutch and German female labour force participation, Plantenga argues that Dutch families were able to achieve a closer match between family reality and the ideology of male breadwinning and female domesticity because of higher (male) labour productivity and higher standards of living in the Netherlands. ${ }^{26}$ Similarly, Hettie Pott-Buter in her seven-country comparison of female labour and family patterns explains the strong male breadwinner character of Dutch society in part by reference to high standards of living. However, apart from economic factors, she also recognizes the decisive importance of the distinctive social structure of Dutch society, as a result of which the bourgeois family came to be the predominant family ideal as early as the seventeenth century. High levels of labour productivity and the pillarization of Dutch society along primarily religious lines ensured the achievement and perpetuation of this family ideal for large parts of the population until well into the $1970 \mathrm{~s}^{27}$

Although these economic models may generally speaking perform relatively well in quantitative analyses of female labour force participation in Westem economies, even economists admit that an approach limited to supply-side variables alone is not adequate when faced with the considerable historical and geographical variation in female labour force participation. ${ }^{28}$ Differences in occupational and industrial structures, as well as in attitudes and industrial traditions are identified as relevant factors to be taken into account. ${ }^{29}$ Moreover, supply-side explanations of female labour

${ }^{25}$ See International Encyclopedia of the Social Sciences, vol. 8 (1968), pp. 478-481, entry: "Labour force: participation, women".

${ }^{26}$ Janneke Plantenga, Een afivijkend patroon. Honderd jaar vromwenarbeid in Nederland en (West-)Duitsland (Amsterdam, 1993). See p. 189.

${ }^{27}$ Pott-Buter, Facts and Fairy Tales, see in particular pp. 319-321.

${ }^{28}$ See Hatton and Bailey, "Female Labour Force Participation in Interwar Britain", pp. 695-718.

${ }^{29}$ Historical evidence shows that working wives were not necessarily married to the poorest workers. Two examples, both relating to industrial textile towns, Preston in England and Enschede in the Netherlands, suggest that the organization of the local labour market based on informal labour recruitment systems may help explain the labour force participation of these wives. See M. Savage, The Dynamics of Working-Class Politics: The Labour 
force participation ignore the gendered positions of men and women in both the family and the labour market, which gave the male household head his customary prerogative as the family's primary breadwinner and made housekeeping and childcare the primary responsibilities of the wife. A perspective which views married women as "added workers" who are "driven" into the labour market in response to changing family needs and/ or changing economic family fortunes argues within the very concept that needs to be clarified.

For this reason, feminist researchers have developed different perspectives which focus on the societal and ideological structures underpinning the male breadwinner family. One of the main approaches in this field, known as the dual systems theory, argues that the male breadwinner family should be seen as the result of contingent historical developments by which a capitalist system was constructed on the basis of pre-existing patriarchal structures and gender practices. ${ }^{30}$ Whilst capitalist modes of production, based on individualized wage labour and the separation of home and work, eroded women's traditional economic roles, patriarchal institutional and ideological structures ensured the continuation of women's subordinate position, for instance through exclusionary strategies and gender differentials in the wage system. The dual systems approach rejects the earlier claim of much Marxist-inspired writing that the capitalist mode of production necessarily required a male breadwinner type of household organization.

Dual systems theory therefore begs the question which groups should be held responsible for the emergence of the male breadwinner family and, consequently, which groups benefited most. At this point, agency enters the historical accounts of the rise of male breadwinning, causing different authors to produce different answers to the question posed. As an important early representative of this approach, Michele Barrett, for instance, argues that the conversion of women into full-time housewives served the interests of the bourgeoisie. Her argument is based on the fact that this particular type of household organization became an important organizing principle of the capitalist relations of production. ${ }^{31}$ To what extent other groups, such as the working-class family or married women themselves, have had an active interest in the male breadwinner family will be discussed later.

Movement in Preston, 1880-1940 (Cambridge, 1987), pp. 74-79; W.H. Posthumus-Van der Goot, Onderzoek naar den arbeid der geluwde vrouw in Nederland (Leiden, 1938), pp. 21-22.

${ }_{30}$ Dual systems theory continues to inform research in the field of women's subordination in the home, at work and at the level of the state. See, for instance, Safa, The Myth of the Male Breadwinner, pp. 37-41.

"M. Barrett, Women's Oppression Today: Problems in Marxist Feminist Analysis (London, 1980), p. 211. 
Another point of contention within the dual systems approach is the question of the status of patriarchy. To what extent should patriarchy be seen as something transcending a set of coherent ideological beliefs and convictions? Some writers argue that patriarchy should be seen rather as an autonomous system with its own political, socio-economic and ideological relations and structures. ${ }^{32}$ It is only then that we can begin to explain why capitalists were prepared to relinquish cheap female labour, thereby subordinating short-term interests in maximizing profits to the longer-run political advantages accruing from a household organization based on male breadwinning.

This argument also provides an initial explanation of why working-class families were prepared to forgo certain short-term financial benefits which their wives' and daughters' labour might bring in exchange for other, non-material signs of value and status. In her article on Indian patterns of breadwinning, Samita Sen presents an example which is illuminating in this connection. She poses the question why families in the Bengal jute and cotton mills did not use their informal, but highly effective, recruitment system to channel their wives, mothers and daughters into the betterpaid jobs such as weaving and spinning. The "nepotism" of male textile workers was extended exclusively to male relatives or fellow villagers, whilst wives and daughters were given the lower-paid jobs in preparing and finishing. This enabled the better-paid males to afford to keep their wives at home, an important symbol of higher social status.

For this reason, authors such as Sylvia Walby and Heidi Hartmann argue that the debate on the male breadwinner family should focus more strongly on the interests of men as men. Working-class men are identified as the central actors in establishing women's subordination within the home. It is suggested that working-class men either drive women out of the labour market entirely or marginalize them into segregated positions at the lower end of the job ladder. In this way they are able to "rescue" their domestic privileges and authority from the threat posed by the spread of individualized wage work. ${ }^{33}$ Protective legislation and job segregation are seen as the principal mechanisms by which working-class men achieve

${ }^{32}$ See, for instance, H. Hartmann, "Capitalism, Patriarchy and Job Segregation by Sex". in Z.R. Eisenstein (ed.), Capitalist Patriarchy and the Case for Socialist Feminism (New York, 1979); idem, "The Unhappy Marriage of Marxism and Feminism: Towards a More Progressive Union", in L. Sargent (ed.), Women and Revolution: The Unhappy Marriage of Marxism and Feminism (London, 1981); S. Walby, Patriarchy at Work (Cambridge, 1986); idem, Theorizing Patriarchy (Oxford, 1990). Other authors also recognize the dynamic dimension of the patriarchal system, which may make it differ historically or cross-culturally. See, for example, Safa, The Myth of the Male Breadwinner, p. 38.

${ }^{33}$ Hartmann, "Capitalism, Patriarchy and Job Segregation by Sex"; idem, "The Unhappy Marriage of Marxism and Feminism"; Walby, Patriarchy at Work; idem, Theorizing Patriarchy. 
their goals. ${ }^{34}$ In recent years, an important modification has been advanced to the way in which dual systems theory identifies male interests as the link between class and gender antagonisms. This approach, which has been developed by Sonya Rose, defines male interests as the wider issue of the preservation of masculine identity rather than as the narrower definition of male domination over women. ${ }^{35}$ Rose argues that masculine identity was rooted in the possession of skill, independence and the ability to organize the family's labour supply. When work was transferred to the factories, men sought to marginalize or exclude women in an attempt to find a new basis for masculine identity. Retaining the skilled and supervisory positions in industry as well as claiming breadwinner's prerogatives in the labour market came to be the key concepts of masculine identity under conditions of industrial capitalism.

In a recent attempt to integrate both "capitalist constraints and proletarian choice" within a setting of patriarchal ideologies, Wally Seccombe distinguishes between different phases of capitalist development. ${ }^{36}$ His main perspective, however, is the analysis of household strategies. In the early stages of industrial capitalism, households relied on a multi-earner strategy in response to capital's "rapacious consumption of labourpower". ${ }^{37}$ Under these circumstances "wages funded merely the daily replacement costs of labour-power, not the full generational reproduction costs". ${ }^{38}$ As capital accumulation proceeded, however, "the vitality, stamina and skills of the [...] urban labour force were not keeping pace with the development of industry". ${ }^{39}$ The second Industrial Revolution necessitated a new production regime based on an intensive mode of labour power consumption, a reduced working week and greater investments in the intergenerational reproduction of labour. Couples responded to these shifts by designating husbands as primary breadwinners and wives as full-time homemakers, a choice which was facilitated by patriarchal ideologies con-

34 These claims are difficult to substantiate. Protective legislation did not always lead to falling participation rates for women; and countries with different legislative measures had similar gender divisions of labour. But judgements differ. See, for instance, C. Goldin, Understanding the Gender Gap. An Economic History of American Women (Oxford, 1990), p. 198; P. Hudson and W. Lee, "Women's Work and the Family Economy in Historical Perspective", in P. Hudson and W. Lee (eds), Women's Work and the Family Economy in Historical Perspective (Manchester, 1990).

${ }^{35}$ See Sonya O. Rose, "Gender at Work: Sex, Class and Industrial Capitalism", History Workshop, 21 (Spring 1986), pp. 113-131; idem, "Gender Segregation in the Transition to the Factory: The English Hosiery Industry, 1850-1910", Feminist Studies, 13, 1 (1987), pp. 163-184; idem, "Gender Antagonism and Class Conflict: Exclusionary Strategies of Male Trade Unionists in Nineteenth-Century Britain", Social History, 13, 2 (1988), pp. 191-208; idem, Limited Livelihoods. Gender and Class in Nineteenth-Century England (London, 1992).

${ }^{36}$ Seccombe, Weathering the Storm, pp. 71-80.

37 Ibid., p. 79.

${ }^{38}$ Ibid., p. 74.

${ }^{39}$ Ibid., p. 79. 
cerning a woman's proper place. ${ }^{40}$ However, like all other models based on different versions of the dual systems theory, Seccombe's is unable to account for the considerable regional and sectoral variations in the extent of married women's employment. ${ }^{4 !}$

In this volume, Sara Horrell and Jane Humphries argue that explanations of the male breadwinner family based on simple and exclusive references to industrial capitalism and/or a universal patriarchal system are untenable in the light of the considerable historical variation that has existed in breadwinning practices, even in England. This conclusion is based on evidence from an extremely interesting dataset of 1,350 British household budgets, covering the period between 1787 and 1865. They demonstrate that the male breadwinner family is the result both of the influence of rising male wages and positive income effects on women and children, and of the disappearance of suitable employment opportunities for women and children. Married women's and children's earnings decreased as industrialization advanced, while at the same time selfprovisioning activities (which had previously represented important economic contributions to the family budget by married women) were curtailed. However, as Humphries and Horrell point out, this overall trend was complicated by considerable variations by region, trade and industry. Factory workers' families, for instance, did not respond to high earnings and labour legislation by adopting a male breadwinner household organization, as did most mining families. Local norms and ample employment opportunities in industrial areas enabled factory workers' wives and daughters to continue their paid employment, further boosting their families' relatively high material living standards.

Other criticisms have been raised against explanations of male breadwinning based on male interests. One of the points made is that current explanations completely ignore the family as an arena for potential class and gender conflicts. ${ }^{42}$ This omission is surprising given the fact that men's desire to preserve domestic privileges is seen as a key factor, and that great importance is attached to an analysis of the labour market in terms of the interaction of both class and gender struggles. Thus, the important question of whether working men and women may not have shared a number of common class-based interests in the male breadwinner family

\footnotetext{
to Ibid., pp. 82-83. In a forthcoming article on Spain, however, Enriqueta Camps has shown that in the Catalan textile industry the second Industrial Revolution actually led to an increase in married women's participation in paid labour, as a substitute for children's work. A reduction in skill qualifications and declining fertility rates together with compulsory schooling for children and a relative improvement of female wages are considered to be key factors. See Enriqueta Camps, "Transitions in Women's and Children's Work Patlems. Implications for the Study of the Family Income and the Household Structure, a Case Study from the Catalan Textile Sector (1850-1925)", The History of the Family. An International Quarterly (forthcoming, 1997).

"Seccombe, Weathering the Storm, p. 114.

42 Creighton, "The Rise of the Male Breadwinner Family", p. 322.
} 
model is completely ruled out, as is the possibility that the male breadwinner family model represents the result of a "cooperative conflict" between male dominance and collective class interests. ${ }^{43}$

A clear example of such a cooperative conflict is presented in Von Oertzen and Rietzschel's article on breadwinning ideologies in the two Germanies between 1945 and 1970. When it was proposed as part of the 1958 West German tax reform to introduce an income tax system based on the principle of equal rights for men and women, thereby denying men a privileged tax status and corresponding financial benefits as the sole family breadwinner, male indignation was such as to abort implementation of the new system. Within the family sphere, the wives gave in to their husbands' protests, as Von Oertzen and Rietzschel indicate, in recognition of the shared family interest in the social respectability associated with the male breadwinner family.

The question of the extent to which men and women shared an interest in the male breadwinner family has been central to studies focusing on working-class demands for a family wage. In his article on the construction of the male breadwinner wage norm, Wally Seccombe argues that the demand for a family wage, whether or not accompanied by demands for outright female exclusion, was related to struggles between families rather than within them. ${ }^{44}$ Similarly, authors such as Humphries have stressed in earlier articles the proposition that the withdrawal of women from the workforce served to maintain working-class living standards through reducing competition in the labour market while providing family members with valuable but unwaged personal care and support. ${ }^{45}$ The accompanying working-class demand for a family wage sought to protect the family, in the interests of both its male and female members, from the undermining pressures of the advancing capitalist system. ${ }^{46}$ In their present paper in this volume, Horrell and Humphries also recognize the potentially beneficial effects of male breadwinning on the working-class family in terms of

43 This concept is derived from Amartya Sen (Resources, Values and Development (Oxford, 1984), pp. 374-376) and denotes a family bargaining model in which all members cooperate to achieve certain outcomes beneficial to all compared with non-cooperation, whilst all parties at the same time have conflicting interests in the choice of effective cooperative outcomes.

"Seccombe, "Patriarchy Stabilized".

4s J. Humphries, "Class Struggle and the Persistence of the Working-Class Family", Cambridge Journal of Economics, 1, 3 (1977), pp. 241-258.

46 The argument that the male breadwinner family served the interests of the working-class family as a whole may also be found in Brenner and Ramas. However, their perspective is different. Brenner and Ramas argue that the gendered division of labour within the working-class family arose out of the conflicting demands between childcare and work outside the home under the conditions of capitalist production. Families opted for the male breadwinner system in order to ensure their family's biological survival. See J. Brenner and M. Ramas, "Rethinking Women's Oppression", New Left Review, 144 (1984), pp. 33-71. 
welfare enhancement, provided male breadwinning was accompanied by increases in male wages.

In the ensuing scholarly debate, demands for a family wage came to be equated with demands for the exclusion of married women (and sometimes girls) from the labour market. ${ }^{47}$ One of the best-known examples is Hall Benenson's critique of Jane Humphries on the basis of a study of Lancashire cotton workers between 1890 and 1914. This shows that wellorganized female workers resisted male attempts to introduce a marriage bar. ${ }^{48}$ Benenson argues that male and female workers had conflicting interests in the labour market and that demands for a family wage served the exclusive interests of male - as opposed to female - workers.

In his contribution to this volume, Mike Hanagan seeks to redress the balance in the debate on the family wage, arguing that it is far from clear that in all cases demands for a family wage also involved demands for the exclusion of married women from waged work. His case study of Stéphanois working-class life indicates the dangers of attempts to generalize from the British nineteenth-century experience. In France, women's participation in the industrial labour force was taken for granted and demands for women's exclusion were therefore rare. However, this did not prevent male workers from using the family wage demand in the face of imminent wage cuts, a demand therefore aimed at ensuring their families' survival. At the same time, however, the survival of the working-class family required the continuation of "multi-stranded relationships" to wage work. The resulting patterns of labour allocation and household organization in the Stéphanois, Hanagan argues, may be explained by reference to the complex interaction between family strategies, labour markets and changing labour relations in the main Stéphanois industries, as well as gendered conceptions of work and ideals of domesticity.

The notion of a male provider responsible for a dependent wife and children is quite clearly a concept originating in Western family ideology. In her paper on patterns of breadwinning in India, Samita Sen demonstrates that the phenomenon of a male breadwinner hardly existed in India before the 1950s. Women's and children's work, based'on a strictly gendered division of tasks and carried out under the authority of male relatives, had been an essential economic component in the functioning of the rural household. However, the introduction of the factory system took men away to the city, to earn the major part of the family's cash needs as migrant workers, leaving women to make a living on the family farm. The fact that women operated at a remove from the emerging modern economic sectors and the urban labour market ultimately made their economic

47 Judy Lown, "Not so Much a Factory, More a Form of Patriarchy: Gender and Class during Industrialisation", in Eva Gamamikow et al., Gender, Class and Work (London, 1983), pp. 11-27; Rose, Limited Livelihoods.

${ }^{48}$ H. Benenson, "The 'Family Wage' and Working Women's Consciousness in Britain, 1880-1914", Politics and Society, 19, 1 (1991), pp. 71-108. 
contributions to the family "invisible" and stripped their labour of any recognized (monetary) economic value. The patriarchal family system, by which husbands and fathers owned the labour of their wives and children, provided the crucial underpinning for this process. ${ }^{49}$ Female labour was manipulated for the benefit of the changing needs of the men in the family, rather than in response to changing demands from employers. In the context of this process the notion of the male breadwinner emerged, originating in elite groups who had adopted Western symbols of social status.

The contribution by Sen also considers the importance of seemingly gender-neutral processes such as capital accumulation and the concomitant rise of large markets. Women's craft activities in India were organized as low-skilled, capital-extensive production processes, and were hence also characterized by low productivity levels. With the development of large capital-intensive, mechanized and highly productive networks of production and trade, women's craft activities became eroded. Limited as they were both by family obligations, and by a lack of skills and capital, women had no access to these newly emerging networks of production and trade. Parallels with the British case as outlined by Horrell and Humphries inevitably come to mind when Sen proceeds to argue that commercialization and pressures on land restricted women's access to woods and common lands, thereby curtailing female trading and self-provisioning.

In his reappraisal of the male breadwinner debate, Colin Creighton stresses the importance of taking into account successive phases in the accumulation of capital and employers' strategies. This may, for instance, help to explain the concentration of women in certain industries in the Western world at times when they were almost absent elsewhere. The inherent danger, however, is a return to "a non-gendered account of the labour market" which overlooks the fact that capital accumulation affected women differently from men because the workforce was already sexually differentiated. Creighton's distinction between these processes and conscious attempts by male employers or male workers to restrict women's employment opportunities is to some extent cosmetic. ${ }^{50}$ The fact that male employers and/or male workers abstained from voicing objections regarding the effects of capital accumulation on a gendered workforce cannot possibly be proof of any conscious, let alone unconscious, motivation they may have had concerning women's economic role.

Capital accumulation and employers' strategies were in a variety of ways "preconditioned by, and built upon, aspects of gender and household economy that originated outside the immediate sphere of industrial

49 Compare for a similar argument on Central and Latin America, Safa, The Myth of the Male Breadwinner, pp. 46-58.

so See Creighton, "The Rise of the Male Breadwinner Family", p. 329. 
production and the labor market". 51 This citation is taken from a study by Don Kalb in which he demonstrates, amongst other things, the relationships between gender, class formation, processes of industrialization and managerial práctices in the Philips company in Eindhoven around the turn of the century. In the successful introduction and consolidation of mass production in the electrical plants, Kalb argues, the Philips management exploited the existence of multi-earner households and the family as a unit of labour recruitment in the low wage area of Eindhoven. These managerial policies secured a steady and massive supply of young, cheap and acquiescent female labour. The Philips example demonstrates how women were brought in almost immediately to fill the highly mechanized jobs in the newer electrical industries, jobs which were labelled "feminine" from the start because they were repetitive, monotonous and required dexterity. ${ }^{52}$ The massive deployment of female labour in the Philips factories did not, however, effect any changes in terms of married women's employment in industry. In the event of their marriage, the "Philips girls" - as they were called - left the factory, so long as company interests permitted it: that is so long as an adequate supply of unmarried female labour was available. ${ }^{53}$ Thus, employers' strategies were to a large extent informed by established cultural notions of appropriate (industrial) work for men and women.

The article by Lina Gálvez in this volume on the Seville tobacco industry presents another informative example of the way in which employers' strategies and the conditions imposed by different phases of capital accumulation influenced the gendering of the workforce. To some extent in the same way as in the case of the Philips company, gender formed a crucial factor in the transition to industrial production. Based on the exploitation of the flexible workforce of skilled female tobacco workers and their household economies, the company's management was able to implement a gradual process of mechanization while maintaining the match between supply and demand. As Gálvez indicates, this transition would have been impossible with a male workforce, since male workers usually operated on a fixed time system. The mechanization of the Seville tobacco industry transformed the company's workforce in fundamental ways: the primarily female skilled workforce composed of family breadwinners and marked by a culture of time flexibility and absenteeism was gradually replaced by a workforce which consisted primarily of male workers on fixed pay and employed on a fixed time schedule in technical, supervisory and maintenance positions, plus a smaller group of young

${ }^{51}$ Don Kalb, "Expanding Class: Power and Everyday Politics in Industrial Communities, North Brabant Illustrations, ca. 1850-1950" (unpublished Ph.D. thesis, University of Utrecht, 1995), p. 13.

${ }_{\$ 3}$ Bradley, Men's Work, Women's Work, pp. 166-171.

33 Annemieke van Drenth, De zorg om het Philipsmeisje. Fabrieksmeisjes in de elektrotechnische industrie in Eindhoven (1900-1960) (Zutphen, 1991), p. 89. 
female workers, the daughters of the old cigarreras, who operated the new tobacco machines to fixed time schedules. The labour allocation policy of the cigarreras' household economy responded to the change by switching over to promoting male labour with the company management. The article by Gálvez is an instructive example of the way in which gender, the family economy and its dynamic labour allocation mechanisms interacted with the wider labour market and employers' labour policies in the subsequent phases of capital accumulation. ${ }^{54}$ However, as Gálvez concludes, for a correct understanding of the outcomes of the interplay between these historical actors, we need to remain aware of their differential and fundamentally gendered positions. The breadwinning cigarreras remained first and foremost associated with family and household responsibilities, and this determined the way they were incorporated into subsequent phases of capital accumulation.

Evidently, if we wish properly to understand the rise of male breadwinning, and in particular the variations that may be found in these patterns, we cannot neglect the influence of the institutional structures of power, as they have become embedded in the modern welfare state. As Lena Sommestad contends in her contribution to this volume, there is no industrialized society in which male breadwinning has been capable of sustaining an adequate national reproductive process without public support. Similarly, Hanagan concludes that it was only with the gradual establishment of a welfare state based on male wage earning in the period after 1914 that French families could begin to contemplate a household organization based on male breadwinning. Moreover, studies indicate that employers and state policies have considerable effect on the different ways in which men and women share productive tasks. ${ }^{55}$ Welfare state formation did not everywhere identify men exclusively as earners and women as carers.

Sommestad's paper designates economic and demographic factors, which combine to form particular reproductive conditions, as key elements in shaping welfare state attitudes towards breadwinning. In this approach Sommestad has constructed two interesting tools for research on the gendering of welfare state formation, by distinguishing between a country's "capacity for reproductive investments" and its "reproductive chal-

st It is tempting to associate this case of female breadwinners with manual production, which allows for greater flexibility in work schedules than mechanized production. That female breadwinning and a fully mechanized production system are not mutually exclusive is demonstrated, however, by Joyce Parr's study of two Ontario towns in the first half of the twentieth century. In Paris, one of these two towns, female breadwinning throughout the family life cycle was made possible in the local textile industry through adaptations by employers, family members, the community and working mothers: see Joyce Parr, The Gender of Breadwinners. Women, Men, and Change in Two Industrial Tow'ns, 1880-1950 (Toronto, 1990).

ss See, for instance, Susan Pederson, Family, Dependence, and the Origins of the Welfare State, Britain and France, 1914-1945 (Cambridge, 1993); and Diane Sainsbury, Gender, Equality and the Welfare States (Cambridge, 1996). 
lenges". Sweden's particular position within this constellation at the beginning of this century paved the way for a "weak male breadwinner state" which was prepared to intervene in the private sphere of the family on the basis of universalistic citizen-based and largely gender-neutral social provisions. Sommestad's model is thrown into relief by a comparison with the construction of the "strong male breadwinner state' in the United States. By developing these gender-relevant dimensions in the genesis of the welfare state, Sommestad also contributes to the mainstream debate on possible welfare state variation. ${ }^{56}$

Ultimately, however, as Von Oertzen and Rietzschel underline in their contribution to this volume, breadwinning practices are the result of struggles and claims fought over in the private sphere of the family, between the spouses. In their comparative case study on the history of the male breadwinner ideology in West and East Germany between 1945 and 1970 , they suggest that - despite huge differences in the rates of women's labour force participation - the underlying ideological differences were considerably smaller. As the crucial factor, Von Oertzen and Rietzschel point to the lack of East German policies aimed at reforming the deeply gendered system of labour division within the family to match the reform of gender divisions within the labour market. The mere fact of East Germany's massive female labour force participation was not sufficient decisively to alter breadwinning ideologies so long as the institutional structures of power continued to define women as earners/carers while men were seen exclusively in their role as eamers. This conclusion dovetails neatly with the importance that is attached in this volume by Lena Sommestad to the intervention in the private sphere of the family by the institutional structures of power. ${ }^{57}$

\section{CONCLUSIONS}

It is clear that the debate on the male breadwinner family abounds with disagreements. There is disagreement concerning the precise historical development of breadwinning patterns, and disagreement concerning the complex of factors explaining the assumed rise and expansion of the male breadwinner family. Disagreement concerning the actual historical and regional development of breadwinning patterns arises out of a lack of direct and systematic evidence on the breadwinning activities of men and

${ }^{56}$ On this debate see, for instance, ibid., pp. 40-44.

57 For a comparable position see Pedersen, Family, Dependence, and the Origins of the Welfare State. Pedersen argues that the weak French male breadwinner system was supported by employers' policies, which were later incorporated into state policies, providing family benefits for both male and fermale workers with children. This undercut male workers' claim for a family wage. Pedersen contrasts the French case with the British system, which directed state efforts more towards protecting the integrity and superiority of male wages, thereby institutionalizing relations of dependence within the family. 
women. This collection of articles first of all identifies the need for an intensification of research effort by historians and social scientists aimed at a systematic and comparative reconstruction of historical breadwinning practices based on family budgets. This reconstruction would have to cover strategically chosen periods and geographical areas, as well as carefully targeted economic sectors and social groups. For this future research agenda to be successful, it is essential that we move away from the heavy focus on north-westem Europe. There is every reason to believe that northwestem Europe does not represent the historical norm. Southern Europe, but above all Eastern European countries, also need to be included. Indeed, it is paramount that we move away from an exclusively European focus and include comparisons with non-Westem histories of breadwinning. Any "European Historical Norm" - or "Asian Historical Norm", for that matter - can by definition only be established through cross-cultural comparison. The present volume therefore calls upon historians and social scientists alike to undertake creative, imaginative and painstaking empirical research in order to determine historical and regional patterns of breadwinning with greater precision.

Second, this volume also makes clear that monocausal theories, with or without explicit claims of universal validity, have lost their explanatory power. Evidently explanations of breadwinning patterns cannot be based solely on exclusive references to patriarchy or to industrial capitalism. Neither can a purely economic model offer sufficient explanation of patterns of breadwinning. Historical and regional variation is too wide for monocausal explanations to suffice. The debate so far had already suggested additional, often interrelated, factors as relevant variables for the study of breadwinning patterns. These range from institutional constraints and local gender norms and attitudes to household strategies, economic differentiation, capital accumulation, the development of large commercial networks, the patriarchal interests of men and the changing structure of local labour markets. However, it is wholly unfruitful to study any of these factors in isolation from the others. The time has now come to move beyond these fragmented accounts towards the formulation of "theories of the middle range" which are both complex and sensitive to historical variation and context. Together, the articles in this volume provide insights into the type of complex realities and connections yielded by this approach. One of the ways to progress in this direction is to develop detailed systematic comparisons in which the various factors which have so far been identified as relevant to historical outcomes are studied in their mutual interrelationships.

Third, the articles in this volume all indicate that the family acted as a central mediator for the construction and preservation of gendered patterns of breadwinning. For this reason, within the research agenda articulated above, particular attention needs to be paid to the way in which family decision-making on labour division interrelated with external factors such 
as institutional constraints, the labour market and economic change. What labour allocation choices did families make, given a particular external constellation, and under what conditions did they opt for dual or perhaps even sole female breadwinning? And if they did not do so, why was this? Counterfactual analysis might be enormously illuminating in this respect, but is unfortunately difficult to implement given the nature of the problem. We need, therefore, to trace the structures that enabled families to pursue alternative routes in order to get a clearer view of determining factors and of the different options available to various social groups. In this connection, ample attention should be paid to conflicting or converging interests within the family and in particular to the interests of women. Their voices are less often heard in this debate, which is surprising given the farreaching consequences breadwinning patterns had for gender relations, both within the family and outside it. We need therefore to examine the precise options and limitations faced by women at any given period, and the motives that led them to make the choices they did.

Calling for the family to become the key focus of future research on breadwinning patterns should not be seen as a circumspect way of introducing a new monocausal explanatory perspective. Rather, taking the perspective of the family in relation to and in interaction with the external factors listed above is the only way we can ever hope to arrive at the type of complex and historically specific explanations that we have set ourselves to achieve without losing sight of the fundamentally gendered positions of men and women in society. It is within the family that gendered external opportunities and constraints converge with equally gendered family patterns and attitudes. This is the framework within which breadwinning patterns are worked out. It is towards this goal that the articles in this volume will, I hope, constitute important advances and in this area that they will provide pointers for future research. 